Sarango-Lapo, C. P., Ramírez-Montoya, M.S. \& Mena, J. (2016). Evidence-based Innovation methodology as a way to produce Open Educational Resources by inservice teachers. In Proceedings of the fourth International Conference on Technological Ecosystems for Enhancing Multiculturality, TEEM 2016. Salamanca, Spain.

\title{
Evidence-based Innovation methodology as a way to produce Open Educational Resources by in-service teachers
}

\author{
Celia Paola Sarango-Lapo \\ Universidad Técnica Particular de Loja \\ San Cayetano Alto \\ cpsarango@utpl.edu.ec
}

\author{
Juanjo Mena \\ Universidad de Salamanca \\ Po Canalejas, 16937009 \\ juanjo-mena@usal.es
}

\author{
María-Soledad Ramírez- \\ Montoya \\ Tecnologico de Monterrey \\ Avda. Garza Sada 2501 sur, col. \\ Tecnológico \\ solramirez@itesm.mx
}

\begin{abstract}
Innovation-based evidence methodology is a newly teaching approach that promotes the use of peer-reviewed information as grounds to design teaching projects. For this to occur three designing stages are needed 1: choosing the object to be studied, 2: searching for evidence in the literature, 3: write the innovative teaching project and two implementation stages: 4: enactment and evaluation, 5: Dissemination which are advised to be accomplished. The completion of those phases may serve to produce Open Educational Resources (OER), which at last, are seen as one of the products of educational innovation. The purpose of this paper is to show what object of study the participant inservice teachers selected for their innovation projects (phase 1) and how they produced OER -methodology- (phase 4) accordingly. Data analysis was conducted using a descriptive exploratory methodology. Results indicate that in-service teachers mainly chose projects in the disciplines of language and mathematics within primary and secondary education levels. On the other hand, Problem based learning (teaching strategy), b-learning (teaching modality) and IDB (teaching resource) were the most used methodologies for OER production. This leads us to understand that language teachers are more prone to design innovative projects in their classrooms. Additionally, they are mostly worried to implement innovative strategies in the OER they produced, rather than teaching modalities or ICT resources.
\end{abstract}

\section{Categories and Subject Descriptors}

Applied computing Education

General Terms

Performance, Design, Experimentation, Human Factors.

\section{Keywords}

Innovation based evidence; open resource education; training in-service teachers.

\section{INTRODUCTION}

Universities and higher education institutions worldwide are immersed in change process to improve their quality teaching processes [21]. The use of Information and Education technology increase the possibilities of the universities to innovate their teaching process, and a way to do it; is by using Open Educational Resources (OER). According to [18] high education institutions requires both teachers and students to integrate learning resources, because they can access to new and flexible content, which allow them to interact better. Therefore, teachers should incorporate them into their classrooms as part of the syllabus, and as a result the teaching-learning process will be more dynamic and interesting.

The use of OER involves some activities to do such as reusing, redistributing, revising and remixing, its use also supports the virtual academic communities by giving the chance to share and disseminate innovative educational practices [16]. Because of this, it is important that teachers have the necessary skills and competences to face new ways of teaching. 
Additionally, the integration of OER in education requires teachers enroll in digital training [20]. Digital Competence is recognized as a key competence for citizens at the $21^{\text {st }}$ century and it highlights technology and pedagogy dimensions [6]. International Organizations have developed a teaching digital competences framework in order to guide and highlight the role of the teacher when using technology [10; 25].

The aim of this paper is to show how in-service teachers of a postgraduate on-line course produce OER as a result of a design and implementation of an innovative project using a strategy called innovation based evidence.

The information shown in this paper could be of the interest OER and innovative education researchers, because it includes some experience of having use, produce and disseminate it. OER allows teachers to innovate their teaching practices supporting it with scientific and update literature, which represents a challenge and an opportunity to go further in this area o study.

This paper has been divided into seven sections. Section 2 describes a framework that supports the proposal research. Section 3 describes the statement of the problem. Section 4 shows research methodology. And section 5 and 6 presents the results and discussion of this research.

\section{FRAMEWORK}

The emergence of Information and Communication Technologies (ICT), particularly Internet, has opened new ways to produce knowledge and disseminate within the Teacher Educators community [19]. One of the way is to develop OER as significant educational tools for equalizing access to education and guarantee free access to them [7]. Disseminate OER allow to know best teaching practice too.

OER has gained acceptance by educational researchers because it brings renewed ways of teaching practice. Teachers Educators have focused their attention on making students' learning with OER as they enables extensive and democratic practices [15]. Also, they are increasingly becoming facilitators who formulate challenges and offer support anytime from anywhere [2]. For that reason, it is important the implication of teachers as main responsible of the use and dissemination of OER as a best teaching practice.

To date, researches have highlighted the role of university and tertiary education as the predominant channel to promote the OER practices as innovative methods for teaching [8]. However, research also highlights that teachers, as active element in education, do not always demonstrate confidence to use open technology (OER) because evidences about good practices on how to use them are needed [3; 5; 23]. Other reason highlights the lack of skills needed to use technology and pedagogical issues $[1 ; 4 ; 14 ; 15]$. It is notorious as mentioned by [17] and [3] that there is a big challenge to face in education, if we want to link the gap between practice and research.

It has been largely recommended that teachers should be trained in the use of OER. According to [25] there is a need for training of ICT in order to improve the teacher's skill. Studies have revealed that teachers do not yet integrate technology effectively into their classroom [5; 9; 22] it is because is necessary pedagogic training [12;13] to successful diffusion and adoption technology or OER. However, [5] mentioned that knowledge is not enough if teacher do not perceive by him/her self-competent in his use.

There is an innovative methodology that allows using, producing, and disseminating OER among teachers; its name is Evidence- Based Innovation in Education (EBIE). [24] mention that there is need for innovation in teaching practices, for guiding teachers to find the best practices and support their own practices, through activities such as finding scientific literature, critical reading, and evidence's evaluation found. At the same way [17] state that teachers should be able to find information, critical reading, and writing projects skills in order to put knowledge into practice through inquiry strategies supported by digital skills.

Therefore, it is widely assumed that EBIE has five steps 1) choosing the object of study, 2) searching for evidence in the literature, 3) write the innovative teaching project, 4) enactment and evaluation, 5) Dissemination.

\section{THESIS STATEMENT 3.1 Problem statement}

It seems that OER is not often used in the daily teaching practice [16], for that reason might be recommended to go for another kind of innovation model which allow for an effective integration: EBIE methodology could be an alternative [24].

\subsection{Research Objectives}

Our interest about this study is to analyze the EBIE model, specifically, how its application can support the use, production and dissemination of OER. In this study we are going to highlight the ability that in-service teachers who participation in an on-line course of a postgraduate program, to designing innovators project (phases 1 to 3) and its implementation (phases 4 and 5). For this study, phase 1 is one of the most representative because it shows how in-service teachers choose the object of study to write an innovator project; and also, phase 4 was chosen because it shows how in-service teachers produced OER.

\section{RESEARCH METHODOLOGY}

The methodology chosen to analyze the data was descriptive- exploratory [11]. This methodology involved the application of phase 1 and phase 4 of the EBIE model. 


\subsection{Sample}

A total of 96 in-service teachers of an on-line postgraduate program, which is called "Modelos de Gestión del Aprendizaje" [Management models for learning] participated in the study. It was taught at the Instituto Tecnológico de Monterrey (ITESM, Mexico) during four months in 2016. Out of the initial sample, 94 in-service teachers completed successfully the on-line course.

\subsection{Data collection}

Data was collected upon three questions of a survey, which was applied to the in-service teachers. The first one was about application level of the innovator project, which involves user level, institutional level and national level. The second one was about educational level, that is to say, the educational degree to be applied in the innovation project (i.e., being educational level according the way of theirs jobs). The third question was about working field (See Table 1).

Data about production of OER was collected from participants" documents and was later uploaded to the learning platform as a result of their learning (See Table 2).

\subsection{Data analysis}

At the end of the on-line course, in-service teachers answered to the question's survey. We analyzed the before three questions regarding to the first and four phases of the EBIE model.

The elaboration of an OER was understand for the purposes of this paper as a research paper produced during and at the end of the implementation of the innovation project in the on-line course.

\section{RESULTS}

Main findings indicate how teachers work in the first step of EBIE. Teachers in the online course needed to start with a planning session where they mark the level they work in the project. Please see Table 1.

Table 1. Choosing the object of study (Phase 1- IEBE)

\begin{tabular}{|c|c|c|c|}
\hline Dimension & Description & $\mathbf{F}$ & $\%$ \\
\hline \multirow{4}{*}{$\begin{array}{l}\text { Application } \\
\text { Level }\end{array}$} & User level & 77 & 80 \\
\hline & Institutional level & 17 & 18 \\
\hline & National level & 2 & 2 \\
\hline & Subtotal & 96 & 100 \\
\hline \multirow{7}{*}{$\begin{array}{c}\text { Educational } \\
\text { degree }\end{array}$} & Kinder & 4 & 4 \\
\hline & Primary school & 35 & 36 \\
\hline & Secondary & 7 & 7 \\
\hline & Post secondary & 45 & 47 \\
\hline & Undergraduate studies & 4 & 4 \\
\hline & Postgraduate studies & 1 & 1 \\
\hline & Subtotal & 96 & 100 \\
\hline \multirow{10}{*}{ Subject matter } & Arts & 5 & 5 \\
\hline & Science & 19 & 20 \\
\hline & Social Science & 4 & 4 \\
\hline & Spanish Language & 12 & 13 \\
\hline & Humanities & 4 & 4 \\
\hline & $\begin{array}{l}\text { English and other } \\
\text { languages }\end{array}$ & 11 & 11 \\
\hline & Mathematics & 20 & 21 \\
\hline & $\begin{array}{l}\text { Educational } \\
\text { Technology }\end{array}$ & 12 & 13 \\
\hline & Other & 9 & 9 \\
\hline & Subtotal & 96 & 100 \\
\hline
\end{tabular}


As shown in table 1,80\% of the in-service teachers chose to conduct an innovation project at a user's level that involved students and educators. Just $18 \%$ mentioned that it is going to be applied to institutional level, which involves administrative staff, librarians and technicians. Only $2 \%$ of the sample chose national level, which involve government, national agencies of accreditation and civil organizations.

Table 1 also highlights that there are $36 \%$ of the in-service teachers who applied their innovation projects at the primary school level and $47 \%$ in post secondary education. Regarding to work field, we can see that Mathematics (21\%) and Sciences (20\%) were the most chosen areas whereas Arts, Humanities and Social Sciences show percentages around 5\%.

Table 2 shows the results of OER produced by in-service teachers.

Table 2. Results of OER produced (Phase 4 - EBIE)

\begin{tabular}{|c|c|c|c|c|}
\hline $\begin{array}{c}\text { Dimensi } \\
\text { on }\end{array}$ & Category & Subcategory & $\mathbf{F}$ & $\%$ \\
\hline \multirow{6}{*}{$\begin{array}{c}\text { Subject- } \\
\text { matter } \\
\text { knowledg } \\
\text { e }\end{array}$} & \multirow[t]{3}{*}{ Sciences } & Natural Science & 17 & 18 \\
\hline & & $\begin{array}{l}\text { Educative } \\
\text { Technology }\end{array}$ & 12 & 13 \\
\hline & & Mathematics & 20 & 21 \\
\hline & \multirow{3}{*}{ Humanities } & Language & 41 & 44 \\
\hline & & Ethical principles & 4 & 4 \\
\hline & & SUBTOTAL & 94 & 100 \\
\hline \multirow{14}{*}{$\begin{array}{l}\text { Methodol } \\
\text { ogy }\end{array}$} & \multirow{4}{*}{ Modalities } & Face to face & 4 & 4 \\
\hline & & b-learning & 13 & 14 \\
\hline & & e-learning & 9 & 10 \\
\hline & & m-learning & 8 & 9 \\
\hline & \multirow{4}{*}{ Strategies } & $\begin{array}{l}\text { Problem-based } \\
\text { learning }\end{array}$ & 20 & 21 \\
\hline & & Flipped learning & 10 & 11 \\
\hline & & $\begin{array}{l}\text { Collaborative } \\
\text { Learning }\end{array}$ & 2 & 2 \\
\hline & & $\begin{array}{l}\text { music-therapy } \\
\text { methodology }\end{array}$ & 3 & 3 \\
\hline & \multirow{6}{*}{ Resources } & White Digital Board & 4 & 4 \\
\hline & & audiovideo book & 4 & 4 \\
\hline & & Offline resources & 4 & 4 \\
\hline & & Electronic portfolio & 11 & 12 \\
\hline & & wiki & 2 & 2 \\
\hline & & SUBTOTAL & 94 & 100 \\
\hline
\end{tabular}

This phase was focus on five domains of knowledge where Language, Mathematics and Educational Technology were the most chosen, and because they are the main competencies.

\section{DISCUSSION}

\subsubsection{About the OER design stage}

EBIE model guides teachers to create and design innovation projects that improve their teaching practice and learning experience. The results at the design stage (phase 1) evidenced how the most in-service teachers choose a designing innovator project to apply in the user level the reason might be explained by the fact that most in-service teachers are not working as a manager or executive and it does not allow them to have the enough resources to implement project in those levels. But it allows as mentioned [15] focusing their attention and efforts on making students' learning a great experience. Furthermore, EBIE model can support in-service teachers to use, create and disseminate OER during the design stage of an innovation project.

On the other hand primary school and post-secondary teachers were the ones that mostly focused on improving their teaching practices through innovation projects. This may be explained by the fact that they have received more training hours on this regard and also because they are required so in their work. Another reason points to the fact those in mandatory educational levels that are being constantly assessed by the educational administration higher levels of ICT knowledge are required. Those reasons highlight that in-service teachers with the support of ICT produced new knowledge through innovation projects [19] leading to innovative teaching practices and the improvement of the learning process [2]. 
It is evident that the most innovative projects were found in the subjects of Natural Science and Mathematics field. Conversely, Social Science and Humanities were few represented showing that science are more prone to open new ways to innovation.

\subsubsection{About the OER Production stage}

OER production (phase 4) revealed two dimensions according to its focus and results: Subject matter knowledge and methodology.

Subject matter knowledge has been divided into Sciences and Humanities. The majority of OER was found in Mathematics and Language, probably because those subjects are representing the key competences from primary to post secondary school.

The methodology dimension showed that the b-learning modality was predominant as well as the online learning types. This may be explained by the characteristics of the school teaching programs.

As for the teaching strategies, in-service teachers showed especial concern in problem-based learning and Flipped learning. Most of the OER focused on them probably because they are novel methodologies greatly encouraged to be used in classroom.

Finally, regarding resources, Electronic portfolio was the preferred technology among the participants, probably because there is a high demand to zoffer students the chance to interact with subject contents and developing digital skills.

The OER produced by the teachers contributed to promote their methods as innovative ways for teaching [8]. On the other hand the training they received in digital skills serve to link teachers' practices with research $[3 ; 17 ; 24]$.

One limitation of this study, though, is the sample size. This fact makes it difficult to generalize the collected results to other school contexts. For that reason we suggest expanding the study sample to other contexts with the purpose to better assess the real impact of OER.

Even though in-service teachers produced OER using EBIE, we believe that it is necessary to continue training teachers with the purpose to develop digital and research skills [17; 24]. This way, they could accomplish an effective integration of OER and technology in classes [5; 9; 22]. Through on-line course we can let the teachers rethink about the role of OER as tools for equal access to education and digital inclusion [7].

\section{ACKNOWLEDGMENTS}

This research work has been conducted under the PhD Programme on Education in the Knowledge Society at the University of Salamanca and thanks to the data collected by the Instituto Tecnologico de Monterrey (ITESM, Mexico).

The authors would like to thank the Universidad Técnica Particular de Loja (Ecuador) for its scholarship to study this PhD programme.

\section{REFERENCES}

[1] Badarch, D., Knyazeva, S., and Lane, A. 2012. Introducing the opportunities and challenges of OER: The case of the Commonwealth of Independent States and the Baltic States. In J. Glennie, K. Harley, N. Butcher, \& T. van Wyk (Eds.), Open educational resources and change in higher education: Reflections from practice (pp. 27-39). Vancouver: Commonwealth of Learning.

[2] Colpaert, J. 2012. The "Publish and Perish" syndrome. Computer Assisted Language Learning, 25(5), 383-391. DOI= http://doi.org/10.1080/09588221.2012.735101

[3] Cook, B., Smith, G. J., and Tankersley, M. 2012. Evidence-based practices in education. In and T. U. (Editors-in-C. C. K. R. Harris, S. Graham (Ed.), APA educational psychology: Theories, Constructs, and Critical Issues handbook (Vol. 1, pp. 493-595). DOI= http://doi.org/10.1037/13273-017

[4] Dimitriadis, Y. et al. 2009. New design approaches to repurposing open educational resources for collaborative learning using mediating arte- facts Conference Item.

[5] Ertmer, P. A. and Ottenbreit-Leftwich, A. T. 2010. Teacher Technology Change. Journal of Research on Technology in Education, 42(3), 255-284. DOI= http://doi.org/10.1080/15391523.2010.10782551

[6] European Commission 2010. European e-Competence Framework 2.0. Framework. October (2010), 1-43

[7] Hussain, I.,Chandio,J., and Sindher, R. 2013. A Study on Attitude of University Academia towards the Use of Oepn Educational Resources in. Pakistan Journal of Commece and Social Sciencies. 7, 2(2013), 367-380.

[8] Hu, E., Li, Y., Li, J., and Huang, W. H. 2015. Open educational resources (OER) usage and barriers: a study from Zhejiang University, China. Educational Technology Research and Development. 63, 6(2015), 957-974. DOI= http://doi.org/10.1007/s11423015-9398-1

[9] Instefjord, E. 2015. Appropriation of digital competence in teacher education. Nordic Journal of Digital Literacy, 2015, 4(2015), 155171.

[10] ISTE. 2008. International Society for Technology in Education (ISTE) Standards for Teachers. (2008), 1-2.

[11] Johnson, A. J. and Gosling, S. 2010. Advanced Methods for Conducting Online Behavioral Research. Washington, D. C.: American "Psychological Association.

[12] Krumsvik, R. J. 2008. Situated learning and teachers' digital competence. Education and Information Technologies, 13, September (2008), 279-290. DOI= http://doi.org/10.1007/s10639-008-9069-5 
[13] Lane, A. and van Dorp, C. A. 2011. Diffusion and adoption of Open Educational Resources. eLearning Papers, 23.

[14] OECD (2007). Giving knowledge for free: the emergence of open education resources.

[15] Parisky, A. and Boulay, R. 2013. Designing and developing Open Education Resources in higher education : A molecular biology project. International Journal of Technology, Knowledge and Society. 9, 2(2013), 145-155.

[16] Ramírez, M.S. 2011. Creación y uso educativo de contenidos digitales en el Movimiento Educativo Abierto: Alcances y retos a través de redes latinoaméricanas. III Congreso de Tecnologías de la Información en la Educación y en la Sociedad: una vision crítica. Barcelona, España.

[17] Ramírez, M. S. 2012. Modelos y estrategias de enseñanza para ambientes presenciales y a distancia [eBook]. México: Editorial Digital.

[18] Rosenberg, M. 2001. E-learning strategies for delivering kwowledge in the digital age. Columbus: McGraw-Hill.

[19] Sánchez, A.B., Mena, J., He, G., and Pinto, J. 2013. Teacher development and ICT: The effectiveness of a training program for in-service school teachers. Procedia: Social and Behavioral sciences. 92(2013), 529 - 534

[20] Sarango-Lapo, C.P. et al. 2015. Prácticas Educativas Abiertas: experiencias de innovación en una institución de educación superior del Ecuador. VIRTUalis. 6, 12 (2015), 217-234.

[21] Salinas. 2004. Innovación docente y uso de las TIC en la Enseñanza Universitaria. Revista Universidad y Sociedad del Conocimiento. 1(2004), 1-16.

[22] Selwyn, N. 2007. The use of computer technology in university teaching and learning: A critical perspective. Journal of Computer Assisted Learning. 23 (2007), 83-94.

[23] Tejedor, F., García-Valcárcel, A., and Prada, S. 2009. A scale for the measurement of University teachers' attitudes towards the integration of ICT. Comunicar. 17, 33(2009), 115-124. DOI= http://doi.org/10.3916/c33-2009-03-002

[24] Tejedor, F. 2007. Innovación educativa basada en la evidencia (IEBE). Bordón : Revista de Orientación Pedagógica. 3 , 59 (2007), 475-488.

[25] UNESCO 2008. Estándares de competencias en TIC Docentes. (2008), 1-28. 